\title{
RETHINKING THE CONNECTION BETWEEN CREATIVE CLUSTERS AND CITY BRANDING: THE CULTURAL AXIS OF PIRAEUS STREET IN ATHENS*
}

\author{
Nicholas Karachalis, Alex Deffner \\ Department of Planning and Regional Development, University of Thessaly, Greece
}

Manuscript received: June 30, 2012

Revised version: October 31, 2012

Karachalis N., Deffner A., 2012. Rethinking the connection between creative clusters and city branding: The cultural axis of Piraeus Street in Athens. Quaestiones Geographicae 31(4), Bogucki Wydawnictwo Naukowe, Poznań, pp. 87-97. 2 photos. DOI 10.2478/v10117-012-0038-0, ISSN 0137-477X.

AвSTRACT. As culture and the arts gain importance within the agendas of cities, the operation of urban creative clusters is manifested as an effective planning tool for rundown neighbourhoods. Artists and cultural businesses (galleries, theatres, design offices, fashion designers, etc.) form a unique and distinctive sector among other sectors of the economy; their effect on the development and image of a particular neighbourhood can be very important. As part of wider urban processes, city marketing and city branding techniques are often used in order to promote the change in these neighbourhoods and, ideally, prevent negative social effects. The main goal of this paper is to present the experience and implications of the - mostly accidental - formation of a creative cluster in Athens (in the areas surrounding the Athenian part of Piraeus Street) and to critically evaluate the potential role of branding, drawing on the experience of similar efforts in other European cities.

KEY WORDS: cultural industries, creative clusters, Athens, Piraeus Street, city marketing and branding

Nicholas Karachalis, Department of Planning and Regional Development, University of Thessaly, Pedion Areos, 38334 Volos, Greece; e-mail:ngkaraha@uth.gr,karachalis@gmail.com

\section{Introduction}

As part of wider urban strategies, place marketing and city branding techniques are used in order to promote change in a city or a specific neighbourhood and, ideally, to prevent problems and ensure citizen participation (Kavaratzis \& Ashworth 2005, Braun 2011). Creative industries and the clusters they form within cities become the subject of separate branding and, often, form a strong, distinct element in their promotion. Often these clusters become the competitive edge of many cities as part of their efforts to position themselves higher up the hierarchies in the context of growing urban competition. The physical elements, the semi-marginal status and the creative atmosphere of these 'cultural neighbourhoods' offer unique opportunities to promote a mixed image, combining cosmopolitan with rebellion elements. Labels such as 'alternative',

An earlier version of this article was presented at the European Urban Research Conference "The City without Limits", Copenhagen, 23-25 June 2011. 
'off, 'edgy' or 'progressive' promote this particular status (Shaw 2005, McCarthy 2006). This is important for artists and craft workers, who depend on their reputation, networking and face-to-face contact more than other groups (Evans 2009, Comunian 2011). Despite the fact that culture-led urban regeneration has been subject to criticism, mainly due to its effects on certain population groups, cultural investment is on the rise and many cities give special attention to new cultural landmarks (Cameron \& Coaffee 2005, Dean et al. 2010).

Culture is considered to be the city's leading high-growth sector, therefore creating conditions for developing clusters within cities has become very popular and the 'creative cluster' has been a buzzword for urban studies the last few years. There is an extended list of recent academic work that links culture to urban development (see among others Scott 2000, Landry 2000, Florida 2002, Markusen \& Gadwa 2010). Creative clusters can have different forms, themes and spatial characteristics or types; a variety of terms are assigned to them - apart from creative ${ }^{1}$ clusters they are referred to as creative or cultural industries quarters, cultural clusters, or cultural districts (Mommaas 2004). UNESCO ${ }^{2}$ defines creative clusters as concentrations that "pool together resources into networks and partnerships to cross-stimulate activities, boost creativity and realise economies of scale". A main distinction is made by different researchers regarding the development path that is being followed, leading to a distinction between institutionally developed if they are planned, and organically developed when they occur spontaneously (Roodhouse 2006, Cooke 2008). Planned creative clusters that follow a development plan combined with a strong place-branding strategy are on the rise - the planning and operation of the Museumsquartier in Vienna forms a characteristic example of the latter (Roodhouse 2006). Santagata (2002) refers to four different types of creative clusters: indus-

\footnotetext{
There is an ongoing discussion regarding the use of the term 'creative' instead of 'cultural' which is not further discussed in this paper - see amongst others Hesmondhalgh \& Pratt (2005) and O'Connor (2009).

2 See UNESCO (2006) "What are creative clusters?" at http://portal.unesco.org/culture/en/ev.phpURL_ID=29032\&URL_DO=DO_TOPIC\&URL_SECTION=201.html [accessed 17 Oct. 2012]
}

trial cultural clusters, institutional cultural clusters, museum cultural clusters, and metropolitan cultural clusters. There is extensive literature on particular case studies; amongst others see Lloyd (2004) on Whicker Park in Chicago, Montgomery (2004) on Temple Bar in Dublin, Heebels \& Van Aalst (2010) on Berlin, Smit (2011) on three cases in The Netherlands, Harris (2011) on Hoxton, etc. For most of these cases, proximity and the development of agglomeration economies are key issues in a sector which is largely based on flexible arrangements and sub-contracting practices.

The notion of creative clusters has been a subject of criticism as well. Pratt (2004) mentions that the liberal and flexible application of this notion has led to overgeneralisation. Others mention the danger of the instrumentalisation of culture (Markusen \& Gadwa 2010, Dean et al. 2010). An important critical view derives from the fact that a concentration or network of cultural industries in a city cannot be compared with practices of a business cluster in the way it is termed by Porter (1998). In the case of Athens and most of other European cities, the preconditions that characterise clusters are not met, as there is no central coordination (usually coordination is done by unofficial, 'loose' associations that do not have the organisational capacity of the leading bodies that operate in other business clusters), there is no common strategy, the educational and research aspects are not so important, and cooperation does not determine the final outcome. Therefore we could say that the term 'clusters' is used in a rather inappropriate way in a city context, since it applies to very few cases - e.g. the case of media clusters (Camagni 1991). Bagwell (2008) also describes the ways creative clusters differ from other business clusters - e.g. the ones defined by Porter - and refers to economic competitive advantages of the cultural industries within creative clusters. Mommaas (2004: 507) conceptualises cultural or creative clusters in his article, where he comments on this variety of features saying, "Projects may restrict themselves to stand-alone buildings or larger building complexes, or they may include entire quarters or networks of locations". He also describes the synergies that are developed within leisure and tourism activity. Chapain \& Comunian (2010) also comment on the different forms creative clusters can take, refer- 
ring to cases of single buildings where a cluster of creative industries is found, and to the difficulty in defining clusters where the boundaries are not clear; instead, they propose a methodology that combines the creative cluster with the notion of the knowledge-pool model. They also provide an extensive list of references for particular case studies of urban creative clusters.

In this paper the limitations of the creative cluster paradigm have been taken into account. It is being used in an urban context on the basis of its spatial characteristics, meaning that proximity and the possibility to develop agglomeration economies are two central elements. For artists and cultural producers searching for low-rent premises and living spaces, networking opportunities and visual quality of space are at the centre of operation. Moving the creative cluster discourse to the city centre creates the need for a wider approach, drawing on current urban geography debates. The term 'cluster' fails to include other aspects and processes of a city centre neighbourhood. In several cases, these are deprived urban areas that continue to face serious social problems even after their 'cultural' transformation (Bagwell 2008, Karachalis 2011). So, the question is whether marketing and branding strategies can be effective as policy tools, and if there are certain ethical considerations that have to be taken into account. Although a city can differentiate or manipulate the images it promotes and use positive cultural images, it must ensure that these new images do not cover up social problems and that they will trigger participatory solutions.

The main research objective of this paper is to examine how and to what extent branding techniques can be of use within cultural clustering strategies, with reference to particular case studies in European cities. Subsequently, the outcomes are examined in the particular case of an extended creative cluster of Athens. The paper integrates findings from a research project on the cultural industries of the city centre of Athens (Karachalis 2007, 2011) with those of recent fieldwork. The initial research was on the evolution and operation of Psiri as a cultural quarter in the 1990s and 2000s that then led to the regeneration of Gazi and Metxourgheion. Initially, the survey sample consisted of 53 enterprises, NGOs and organisations in the Psiri area, but this sample was extended to neighbouring areas. Interviews were conducted with representatives of the cultural industries. Apart from the above, separate interviews were conducted with representatives of the main stakeholders and some of the artists and cultural enterprises that moved out of the area recently. The current situation after the economic crisis was covered by a supplementary research, the outcomes of studies carried out by other researchers and students from the Department of Planning and Regional Development of the University of Thessaly and elsewhere (Mavratzas 2008, Loukogeorgaki et al. 2010, Goni \& Deffner 2011, Ginati 2011, Maragou 2012), but use was also made of inputs from the current debate about the future of the metropolitan area of Athens (Maloutas 2007, Souliotis 2012).

\section{The image of urban creative clusters}

The contemporary image of many cities and their destination marketing strategies are based on cultural production and consumption; museums, art festivals, fairs, concerts, etc. appear as main elements in promotional material (Kotler et al. 1999, Evans 2009). Cross-comparing different cases needs a common research framework and special attention to the different national and local circumstances, as creative clusters tend to follow different development paths. For example, in Berlin, neighbourhoods such as Prenzlauer Berg and Kreuzberg have based an important part of their transformation on housing and an innovative, creative milieu which soon started attracting tourism (Heebels \& Van Aalst 2010). This sudden tourism development led to congestion and other problems; in the case of Kreuzberg, its touristification brought complaints about tourists "rattling sleeping residents out of their beds as they drag trolley suitcases over the cobblestones on their way to catch an early Ryanair flight" ${ }^{\prime \prime}$. Prenzlauer Berg is quite a unique case: even before the reunification of Berlin it attracted artists and people who were opposed to the regime. After the fall of the wall it attracted a second wave of artists and

\footnotetext{
The Local, "Berlin's Kreuzberg decries tourist swarms", 4 March 2011, www.thelocal.de.
} 
students, and nowadays Prenzlauer Berg has entered a new phase in its lifecycle, as the pioneers of the 1990s have lived there for nearly 20 years and are now pushed out. Branding is important: in her work on cultural quarters in The Netherlands, Smit (2011) indicates the importance of the subjective perception of visual elements by cultural entrepreneurs and the way it affects their presence. 'District branding' or 'neighbourhood branding' can even have an effect on the whole city; in some cases a small part that might consist of a few streets is expected to brand or rebrand a whole metropolitan area. For example, the South Bank with the London Eye, Tate Modern and the Millennium Bridge have become the new image of London (Ashworth 2010, Dean et al. 2010).

Although Temple Bar in Dublin cannot be characterised as a clear case of an organically developed cluster, the presence of the cultural industries in its development has been vital; still, the role of the state authorities and the City Council has been decisive at all phases (Montgomery 2004). The area did not succeed in avoiding the negative images of a tourist area or a nightlife destination, but today it seems to be trying to leave these images behind. Boosting this particular area has been a concern of the local enterprises and the major tool here has been the organisation of events that can attract all kinds of visitors and also involve the locals (Rains 1999, Roodhouse 2006). These events are organised the year round and especially at weekends, creating a notion of a continuous programme. Its branding as a destination of creativity and leisure can be characterised as successful and the effective use of the Internet and social media has brought extra attention (see www.visit-templebar.com). This does not mean that everything is positive; critics refer to a 'strong yuppie flavour' and expensive rents that do not allow younger artists to move into the area (Teegan 2010). Raval in Barcelona followed a different path. A characteristic central city area just behind the tourist Ramblas, it has been associated with industrial uses connected with the harbour since the church started selling its land there in the $19^{\text {th }}$ century. After the Second World War, and until recently, it attracted immigrants from Spain and, later on, from African countries. Soon students started moving in, creating a lively at- mosphere (Miles 2004). Prostitution and drug use were dominant until the early 1990s and are still present today. The flagship architecture building of the Museum of Modern Art (MACBA, see Photo 1), the Centro de Cultura Contemporània de Barcelona (CCCB), and a further attraction of cultural industries, shops, cafés, a five-star hotel, etc., created the preconditions of a cluster (Miles 2004). The sudden development of the area and the new buildings and façades attracted critics claiming that the solutions were inauthentic (Degen 2008). One of the most intriguing characteristics of Raval is that there have been attempts to promote the area as an authentic Mediterranean neighbourhood where one can live the genuine experience of Barcelona as opposed to the tourist Gothic Centre or the waterfront (Bataglia \& Trembley 2011). A quite successful promotion activity was launched with "ravalejar", an invented word that tried to capture the feeling of the neighbourhood (Degen 2008, 2010). Apart from that, the local community has tried to create conditions for openness and participation through street events, guided tours, special activities for excluded groups such as Muslim women, etc. Critical views refer to the commodification and institutionalisation of culture in cases such as Raval, Prenzlauer Berg and many others, as the real-estate market soon leads to the displacement of the initial inhabitants and users (Miles 2004, Degen 2010, Martí-Costa \& Miguel 2012).

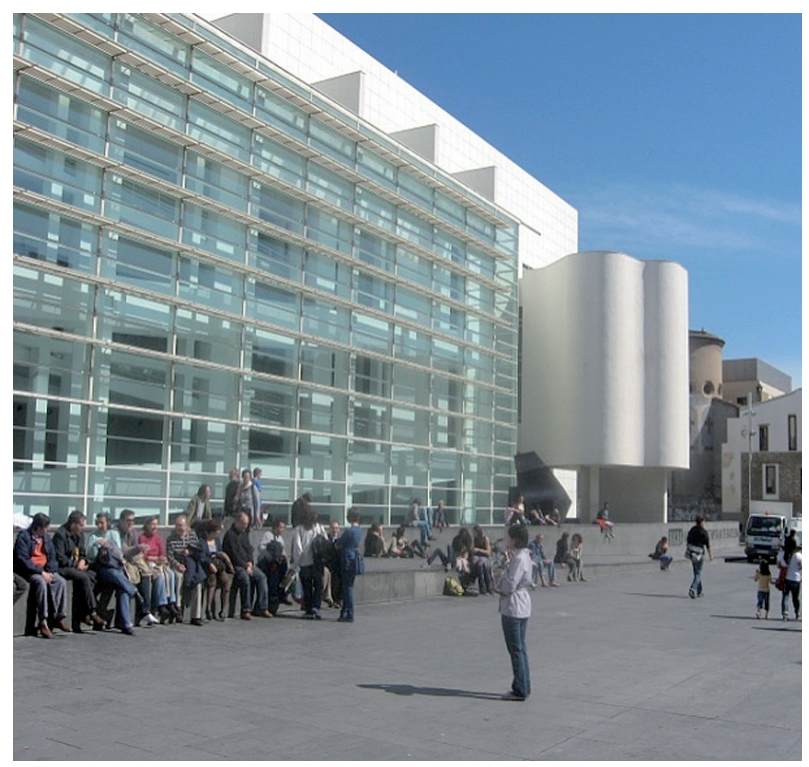

Photo 1. El Raval, the MACBA museum. Source: Nicholas Karachalis. 


\section{The cultural axis of Piraeus Street in Athens: strengths and constraints}

In Greek cities, the formation of creative clusters and the issue of culture-led regeneration in general has not been a priority on local agendas, despite the fact that many cities are making efforts to improve their position as tourism destinations (Gospodini 2006). In practice, there are only a very few cases where such creative clusters have emerged. The quarters of Psiri, Metaxourgheion and Gazi in Athens and Ladadika and Valaoritou in Thessaloniki are the most characteristic examples. This paper deals with the case of the creative cluster that has formed around Piraeus Street and three neighbouring quarters in Athens, each area with its own characteristics. Psiri, Gazi and Metaxourgheion belong to the municipality of Athens and host many cultural industries and some of the most important cultural institutions of the city, such as the Gas Complex, the Benaki Museum and the Municipal Art Gallery. The three quarters form a new wider cluster connected by the axis of Piraeus Street, which connects Athens to its harbour Piraeus; in the $20^{\text {th }}$ century it was associated with industrial development, while after 1990 and its de-industrialisation there have been plans to promote cultural uses. Today the wider area around Piraeus Street hosts a relatively large number of cultural organisations, museums, theatres, music stages, galleries, design offices, fashion designers, etc. These cultural industries are heterogeneous in their operation and the views of their owners on their neighbourhoods differ, as most of them seem to appreciate the symbolic value of the area in different ways. The notion of a cluster is evident - most of the representatives of the cultural industries recognised the importance of networking - but in terms of operation it could become stronger and more effective. The development of the three neighbourhoods into an extensive creative cluster was gradual and did not happen simultaneously.

Psiri was the first one to attract theatres, galleries and artists in the late 1980s, at a time when the area had a marginal status. The cheap rents, the old warehouses that were being transformed into 'lofts' and the artistic atmosphere soon started attracting more cultural industries. Many lei- sure businesses followed, creating congestion, traffic problems and negative images. After 2000 the 'Psiri effect' was conceptualised as an example of poor planning for similar initiatives. Still, until today and despite the negative media image, there is a stable concentration of cultural industries in the area (Karachalis 2011). Especially in the case of the art galleries, there is a strong representation regarding the art market at a national level, as Psiri has an important concentration of art galleries. In Gazi, which was the next district that started attracting attention at the end of the 1990s, the emphasis was given to leisure activities and real estate rather than cultural production - it was also labelled the 'gay village' of Athens (Ginati 2011, Goni \& Deffner 2011). Still, an important number of theatres, music stages, dance schools, etc. create an interesting mix of uses, while the Benaki Museum is an important cultural node. The Gas Complex from which the area gets its name, now a municipal cultural centre, has not been able to attract visitors on a daily basis $^{4}$ or to become a meeting point for the local inhabitants (Maragou 2012).

Metaxourgheion got its name from the old silk factory (which now hosts the Municipal Art Gallery), and for many years has been a transitional area between the commercial centre and the industrial area of the city. The area has attracted many cultural industries most recently, among them some from Psiri, whose owners -disappointed by their old neighbourhood - decided to cross Piraeus Street. It must be noted that a significant number of pioneers from Psiri can now be found here. The empty housing stock which consists of early $20^{\text {th }}$-century buildings has attracted the attention of developers and the 'new middle class'. A new block of luxurious apartments has been created at a central point in the area in Myllerou Street and there are plans for similar developments; at the same time, the artistic community is becoming more visible by hosting special events. The new municipal gallery, which was opened last year, the operation of the experimental scene BIOS, the National Film Archive, theatres, dance

4 The example of the Westergasfabriek in Amsterdam shows how such an initiative can bring an extravert attitude to its neighbourhood; in the case of Gazi, however, there was a lack of effective programming (Koekebakker 2003). 
schools, etc., and the initiatives of the new inhabitants all create new conditions for further development and attract other cultural uses (Mavratzas 2008).

One of the main characteristics of the place identity of this wider area is that it also includes major archaeological and historical elements combined with traditional crafts. The ancient cemetery of Kerameikos - the Dimosio Sima, the ancient Holy Road leading to Eleusis, are all elements that create conditions for the development of heritage tourism in the area. Until today, the tourist appeal of this wider area has been limited. Another interesting fact is that here one can still find small shops specialising in crafts such as leather processing, candle making, repair of musical instruments, furniture making, and so on. Today, despite the pressures of realestate companies, a unique network of specialised streets (leather processors, spice shops, etc.) and historical shops (old taverns, bakeries, etc.) follows the historical patterns of the city. Here there is a double danger: these uses can easily be pushed out by the cultural transformation of the area (some of them have already closed down), while, on the other hand, if protection measures are promoted the danger of touristification will be evident. In many cities, such areas are protected in such a way that visitors get the feeling they are walking amidst a permanent collection, and inhabitants feel unwanted. As the tourist industry tries to sell the experience of these quarters to visitors, historic quarters are in danger of facing a paralysis - in Athens this is a major issue for Plaka. For the operation of creative clusters, historical legacy holds an important role: a gallery owner in Psiri claims that "foreign artists are ecstatic about the area's images; they feel as if they are in a playground... If this is lost the area will lose its artistic atmosphere".

Cultural clustering has occurred through accidental circumstances and has not been enforced by measures or policy at any stage (Gospodini 2006, Karachalis 2007, Souliotis 2012). As one of the designers in Psiri said, "the way we start up businesses and operate within a network is not being understood by policy-makers". A film producer said, "My network is not local, but I do have business relations with other users of my building". An interesting fact is that many of the entrepreneurs and employees have chosen to live here as well. A fashion designer refers to the feeling "of living in a village, seeing friends in the street, meeting in taverns and exchanging ideas". Most of them are micro-entrepreneurs that face survival difficulties. Surprisingly enough, many of them own the premises they work in; in Psiri the percentage is $32 \%$ (Karachalis 2007). This is connected with the general high percentage of house ownership in Greece, but is also a strong indication of a commitment to the creative cluster (Maloutas 2007). Furthermore, the operational objectives of community building and the possible positive outcomes of a branding strategy at a local level have not been discussed so far.

\section{Exploring the connection of the creative cluster with city branding in Athens}

City branding has not been able to get a central position on the agenda of Greek cities. In the case of Athens, this is rather unexpected as one would think that the experience of organising the 2004 Olympic Games would have created the conditions for a long term re-branding strategy (Beriatos \& Gospodini 2004). In the case of Athens, as opposed to that of Barcelona, we cannot refer to a long-term successful Olympic legacy regarding the image of the city, despite the fact that the creation of new cosmopolitan landscapes and buildings, such as the New Acropolis Museum, the promotion of events - e.g. the Athens Festival - and the modern transport infrastructure have been able to attract tourist attention (Gospodini 2009). Of course, after 2010 the economic crisis with the following austerity measures, the humanitarian problem of immigrants, and the rise in criminality have led to a critical situation in many parts of the city centre. Still, the effort to increase the number of tourists continues, with a new, extended city branding strategy under the slogan of "Breathtaking Athens" ${ }^{5}$. Neighbourhood or district packaging and branding can take different forms and serve various objectives. Clearly it is not only a tool for attracting visitors, as it can cre-

See the Breathtaking Athens website: www.breathtakingathens.gr. 
ate a common image and a shared vision for its residents (Ashworth \& Kavaratzis 2010, Sneed et al. 2011). The way a creative cluster is developed - either according to a plan or spontaneously is the key factor that determines its success and image. When a master plan is followed and the leadership is clear, the decision-making process and the monitoring of a specific branding strategy seems to be easier and more effective. When these clusters emerge spontaneously, a branding strategy becomes difficult to plan and implement, and negative images are difficult to prevent.

The latter is the case of the Piraeus Street area, where different problems have not allowed the promotion of a new image linked to its cultural transformation. It has to be mentioned that until recently there has not been a commonly-agreed vision regarding this part of Athens. According to an actor and theatre co-owner, "The development of the area into a leisure park has destroyed it. I avoid walking in the streets with bars during the evening". Another theatre manager, though, said "For my business, the operation of the leisure industry is vital, let us not forget this is not a suburb but the centre of the city". Despite media attention and the recent interest by researchers, the conversion is still at an early stage; lately the discussion has shifted towards criminality and surveillance measures. As a main strength, we can spot the fact that the Unification of Archaeological Sites of Athens has influenced the daily operation of the old city centre ${ }^{6}$ and created conditions for a new image in Athens. The threat of touristification and the creation of an environment of staged authenticity (or a place that does not relate to the historic circumstances) is quite strong (Urry 1990/2002). This project has also had a major impact on the three areas, creating new pedestrian routes with high visibility of ancient ruins in the area. According to the plans, the pedestrian routes will continue towards the Academy of Plato, creating a new tourist axis within Metaxourgheion and the Dimosio Sima. The metro network has had a major impact on

The ambitious Unification Project of the Archaeological Sites of Athens has changed the whole infrastructure and urban design between the archaeological sites, creating new pedestrian and green spaces around the Acropolis; Psiri, Metaxourgheion and Gazi are at the edge of this project (www.astynet.gr). the number of visitors, but also on the character of these areas. Especially in the case of Gazi, the opening of the metro station has drastically increased the number of daily visitors. Interestingly enough, the metro station has also 'given' a new name to the area, Kerameikos (which previously only referred to the archaeological site): obviously this renaming tries to capture the new developments.

The stakeholders' limited involvement is certainly a weakness: both the state and the local government have been unable to follow a coherent plan. This is connected with the general lack of consultation processes or local participation in decision-making processes in Greek cities. Of course, the fact that cultural industries are only part of the daily operation of the inner city neighbourhoods referred to in this article is very important: shop owners, retailers, old and new inhabitants, ethnic groups, etc., are part of their daily life without, though, connecting themselves to the cultural atmosphere. Here a major threat derives from difficulties in inspiring a feeling of belonging in the different users of the Athens city centre. This leads the conversation to the general lack of a vision regarding future priorities of Athens in general. Still, despite the threats and the difficult situation created by the current economic situation, new opportunities occur that create certain positive expectations. First of all, pressure groups that arise out of local communities have gained importance and are now playing a new major role (e.g. the voluntary group called Atenistas; see www.atenistas.gr). Major opportunities are connected with the various artistic initiatives (the Psiri Design Walk, Biennale, Remap KM, Kunsthalle, etc.) organised in Psiri, Gazi and Metaxourgheion during the last few years - despite the fact that these initiatives are also accused of being "gentrification efforts" (Loukogeorgaki et al. 2010). Nevertheless, four out of five interviewees mentioned the poor opportunities to show their work, and therefore a commonly organised event can have important positive impacts. In some cases, efforts for common projects or promotion have failed: a gallery owner describes the experience of organising a successful open-doors event during the 2004 Olympics as "a total disaster as it did not attract any attention and since then there have been no 


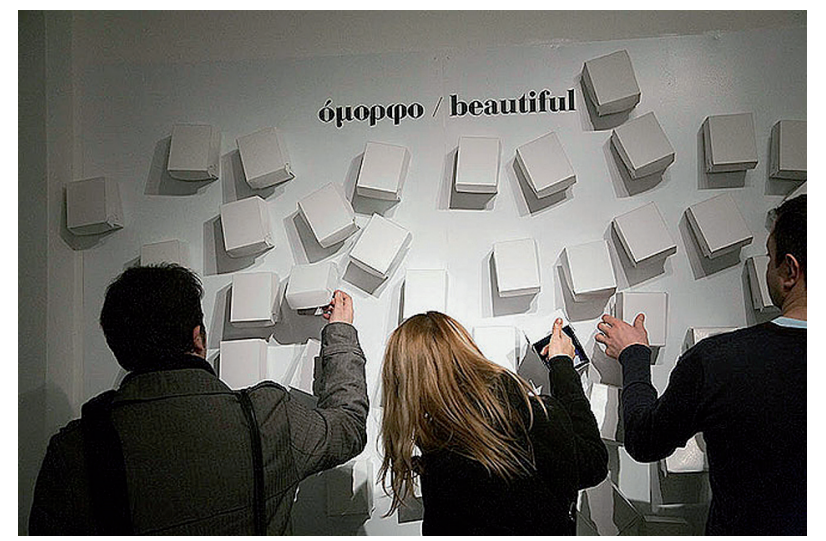

Photo 2. The Design Walk.

Source: Cathy Cunliffe, www.designwalk.gr.

similar initiatives". One profound example is the successful implementation of the Design Walk, which has been organised annually during the first weekend of February since 2007 (after 2010 biannually) and consists of many autonomous expositions in the field of graphic design. The participators organise expositions and present works at their Psiri offices that cover a wide range of visual communications, such as typography, video, animation, installations, photography, etc. According to Alexandros Gavrilakis ${ }^{7}$, more than 4,000 visitors came to Psiri in 2010 during the event, "including organised student groups, young artists, families, or even advertisers that came for fresh ideas". Media coverage is important and despite the fact that the event does not always refer to Psiri (it has a different theme each time), it contributes to a change in the perception of the wider public. According to another gallery owner active in a wider area since the beginning of the 1990s, "any effort to join forces has always been abandoned a few months later". Recently, there have been many openings of collective art spaces in different parts of Athens that indicate a tendency for the operation of shared premises by artists.

\section{Conclusions}

The article reports the main points of our investigation of how cultural industries and professionals that operate within creative clusters

A designer, member of the organisation (personal interview, 22 Dec. 2011). in Athens make use of their networks and affect wider operation and promotion at the city level. It is clear that Athens is not a representative case study as the notion of a creative cluster has not developed here in the same way as in other European cities. Nonetheless, many of the characteristics of the areas around Piraeus Street can be traced in other examples as well. The latest developments after the sovereign debt crisis in Greece have made the situation even more difficult for the whole city centre. Currently the discussion on creative clusters is therefore limited; on the other hand, the future of the centre of Athens is in the spotlight with many newly announced plans and debates (e.g. the incentives for young couples to move to the area, the "Rethink Athens" debate, and the contest on the regeneration of a central axis of the city, see www.rethinkathens.gr).

The concept of creative clusters is only briefly reviewed and not presented in an exhaustive way. It is a buzz term that needs further clarification since it is used for a variety of cases that do not share similar characteristics. Despite its popularity, the term is not the most suitable for this type of urban auto-regulated networks (Pratt 2004, Chapain \& Comunian 2010). The branding strategies of creative clusters also differ; still, one can spot some common ideas and themes. First of all, these clusters are popular with city marketers because of their semi-marginal status and unique atmosphere. The so-called alternative or "off" scene (graffiti, street art, etc.) can become a powerful branding tool for a city - the notion of "guerrilla marketing" comes up as well. This leads to a dual attitude towards this scene, e.g. graffiti is a strong tool for city marketers but is also connected with the "broken window syndrome" (Iveson 2010). The success of these clusters often leads to the loss of their alternative status. Secondly, the efforts to package and promote a certain image and experience for tourists is linked to the danger of 'Disneyfication'; in the case of Temple Bar and Prenzlauer Berg, this is quite evident. Although talking of gentrification on such a scale is rather exaggerated, it is a problem that strikes the artistic community - to some extent, this is the case in Athens as well. Furthermore, a creative cluster has to try to incorporate other users too and encourage their participation in and support for its operation; rivalry or ten- 
sions can occur when this is not the case (Zheng 2011). Although city branding is connected with urban planning (Deffner \& Metaxas 2008) and its role can be important in creating the conditions for this participation and dialogue, it must not be confused with urban planning tools. Even more important is the role of city branding in developing new narratives related to the lifestyles and symbolic capital of these neighbourhoods, and creating conditions in order to achieve social goals (Mommaas 2002).

In Athens and the areas around Piraeus Street, many cultural businesses face survival problems because of the downgrading of the city centre and the current economic situation, making any attempt to forecast its future difficult (Rigopoulos 2012). Despite the attractiveness and positive historical elements of the area, it has not been possible to create viable conditions for the cultural industries, and nowadays it seems that a point has been reached where coordination problems, lack of planning of infrastructure for visitors, the many complaints by the users, and lack of a shared vision for the future have led to an uncertain situation. The lack of a sense of ownership of the area, conflicts between the main groups of interest, alongside the fact that there is no conceptualisation of the cultural status, are the main differences between this case and similar ones in European cities. In such cases as Temple Bar, Raval, Prenzlauer Berg or the Northern Quarter in Manchester, an association or the city council holds the key role in the planning and development process and cultural programming or partnerships. In Athens the city authorities have not been able to interfere at any stage of development since they are not a major land owner and seem to be incapable of comprehending the special dynamics of the neighbourhood. The larger cultural organisations that operate around the Piraeus axis have shown no interest in opening to neighbourhood initiatives and are not important elements as in other cases, e.g. the MACBA.

It is not the intention of this paper to propose a strategy for the newly-developed Athenian creative clusters or to propose a specific branding strategy, but to critically evaluate their experience compared with similar efforts in other cities. Although it can be argued that the Barcelona, Dublin and Berlin cases are at different stages of their lifecycle and have not always been characterised by the same positive image, elements of their strategies definitely can be used as an example of best practice. Of course efforts to copy another example can lead to the projection of homogeneous images and outcomes. In the case of Athens, most of the cultural entrepreneurs and professionals interviewed have admitted to having been inspired by similar cases in London, Berlin or New York, and they have chosen to come to these parts with the hope of witnessing the same development (Karachalis 2007). One can easily observe the production of similar, often homogeneous images: cosmopolitan, globalised images of cultural consumption (museums, galleries, etc.), 'controlled' alternative cultures, and the notion of a staged 'rebellious' urban experience. In line with other studies on creative clusters, we feel that future research should further investigate how the networks of cultural industries operate, their possible role in participatory planning procedures, and the way branding strategies can positively affect their future.

\section{References}

Ashworth G.J., 2010. Personality association as an instrument of place branding: Possibilities and pitfalls. In: Ashworth G.J \& Kavaratzis M.(eds), Towards effective place brand management: Branding European cities and regions. Edward Elgar Publishing, Cheltenham, 285-303.

Bagwell S., 2008. Creative clusters and city growth. Creative Industries Journal, 1: 31-46.

Bataglia A. \& Tremblay D., 2011. El Raval and Mile End: A comparative study of two cultural quarters in Barcelona and Montreal. Between urban regeneration and creative clusters. Research note no 2011-1A, Canada Research Chair on the Socio-Organizational Challenges of the Knowledge Economy, University of Quebec, Quebec.

Beriatos E. \& Gospodini A., 2004. Glocalizing urban landscapes - Athens and the 2004 Olympics. Cities, 21 (3): 187-202.

BRAUN E., 2011. Putting city branding into practice. Journal of Brand Management, 19 (4): 257-267.

CAmagni R., 1991. Introduction: from the local 'milieu' to innovation through cooperation networks. In: Camagni R. (ed.), Innovation networks: Spatial perspectives. Belhaven Press, London, 1-9.

Cameron S. \& Coaffee J., 2005. Art, gentrification and regeneration - from artist as pioneer to public arts. European Journal of Housing Policy, 5 (1): 39-58.

Chapain C. \& Comunian R., 2010. Enabling and inhibiting the creative economy: The role of the local and regional dimensions in England. Regional Studies, 44 (6): 717-734. 
Comunian R., 2011. Rethinking the creative city: The role of complexity, networks and interactions in the urban creative economy. Urban Studies, 48 (6): 1157-1179.

CoOKe P., 2008. Culture, clusters, districts and quarters: Some reflections on the scale question. In: Cooke P. \& Lazzeretti L. (eds), Creative cities, cultural clusters and local economic development. Edward Elgar, Cheltenham: 25-47.

Dean C., Donnellan C. \& Pratt A.C., 2010 Tate Modern: Pushing the limits of regeneration. City, Culture and Society, 1 (2): 79-87.

Deffner A., Metaxas T., 2008. Is city marketing opposed to urban planning? The elaboration of a pilot city marketing plan for the case of Nea Ionia, Magnesia, Greece. In: Psycharis Y. \& Skayannis P. (eds), The contexts, dynamics and planning of urban development. University of Thessaly Publications, Volos: 129-160.

Degen M., 2008. Sensing cities: Regenerating public life in Barcelona and Manchester. Routledge, London.

Degen M., 2010. Consuming urban rhythms: Let's ravalejar. In: Edensor T. (ed.), Geographies of rhythm. Ashgate, Aldershot: 21-32.

EBert R. \& KunZMAnN K., 2007. Kulturwirtschaft, kreative Räume und Stadtentwicklung in Berlin. DISP, 171 (4): 64-79.

Evans G., 2009. From cultural quarters to creative clusters: Creative spaces in the new city economy. In: Legner M. \& Ponzini D. (eds), The sustainability and development of cultural quarters: International perspectives. Institute of Urban History, Stockholm: 32-59.

Florida R., 2002. The rise of the Creative Class: And how it's transforming work, leisure, community and everyday life. Basic Books, New York.

GinATI E., 2011. The role of cultural quarters in urban regeneration: Gazi. Unpublished master's thesis, Panteion University, Athens.

Goni K. \& Defrner A., 2011. The transformation of former industrial areas into cultural and leisure quarters: The case of Gazi in Athens. Paper at the Hellenic ERSA Conference Regional Development and Economic Crisis, Panteion University, Athens, CD-ROM (in Greek).

Gospodini A., 2006. Portraying, classifying and understanding the emerging landscapes in the post-industrial city. Cities, 23 (5): 311-331.

Gospodini A., 2009. Post-industrial trajectories of Mediterranean European cities: The case of post-Olympics Athens. Urban Studies, 46 (5-6): 1157-1186.

HARRIS A.J., 2011. Branding Hoxton: Cultural landscapes of postindustrial London. In: Pike A. (ed.), Brands and branding geographies. Edward Elgar, London: 187-199.

Heebels B. \& Van Aalst I., 2010. Creative clusters in Berlin: Entrepreneurship and the quality of place in Prenzlauer Berg and Kreuzberg. Geografiska Annaler, Human Geography Series, 92 (4): 347-363.

Hesmondhalgh D. \& Pratt A.C., 2005. Cultural industries and cultural policy. International Journal of Cultural Policy, 11 (1): 1-13.

IVESON K., 2010. Graffiti , street art and the city: Introduction. City, 14 (1-2): 25-32.

Karachalis N., 2007. Culture and local development: The role of cultural quarters and tourist areas in the contemporary city. $\mathrm{PhD}$ thesis, Panteion University of Athens, Athens (in Greek).

Karachalis N., 2011. The regeneration of inner city neighbourhoods and the role of cultural industries: The case of Psiri in Athens. In: Cremaschi M., Eckhard F., (eds),
Changing places, urbanity, citizenship, and ideology in the new European neighbourhoods. Techne Press, Amsterdam, 142-159.

Kavaratzis M. \& Ashworth G.J., 2005. City branding: An effective assertion of identity or a transitory marketing trick? Tijdschrift voor Economische en Sociale Geografie, 96 (5): 506-514.

KoeKebaKKer O., 2003. The Westergasfabriek Cultural Park, the transformation of a former industrial area. NAI Publishers, Rotterdam.

Kotler P., Asplund C., Rein I. \& Haider H.D., 1999. Marketing places Europe: Attracting investments, industries and visitors to European cities, communities, regions and nations. Financial Times Prentice Hall, Harlow.

LANDRY C., 2000. The creative city: A toolkit for urban innovators. Earthscan Publishers, London.

LLOYD R., 2004. The neighborhood in cultural production: Material and symbolic resources in the new bohemia. City and Community, 3(4): 343-372.

Loukogeorgaki A., Patelida M., Somarakis G \& Tziaferi E., 2010. Cultural profile and marketing: The case of Gazi, Metaxourgheio and Psiri in Athens. Paper, Undergraduate Programme in the Department of Planning and Regional Development, University of Thessaly, Volos (in Greek).

MaloutA, T., 2007. Segregation, social polarisation and inequality in Athens during the 1990s: Theoretical expectations and contextual difference. International Journal of Urban and Regional Research, 31 (4): 733-758.

Maragou D., 2012. Strategies for the re-use of postindustrial buildings for cultural purposes: The Technopolis of the municipality of Athens. Unpublished master's thesis, Hellenic Open University, Patras (in Greek).

Markusen A., Gadwa A., 2010. Arts and culture in urban or regional planning: A review and research agenda. Journal of Planning Education and Research, 29 (3): 379-391.

Martí-Costa M. \& Miquel M.P., 2012. The knowledge city against urban creativity? Artists' workshops and urban regeneration in Barcelona. European Urban and Regional Studies, 1: 92-108.

Mavratzas V., 2008. Culture and leisure cluster in the postindustrial city: The case of Metaxourghio in Athens. WIT Transactions on Ecology and the Environment, 117: 235-244.

McCARTHY J., 2006. Regeneration of cultural quarters: Public art for place image or place identity? Journal of Urban Design, 11 (2): 243-262.

MiLes M., 2004. Drawn and quartered: El Raval and the Hausmannization of Barcelona. In: Bell D. \& Jayne M. (eds), City of quarters: Urban villages in the contemporary city. Ashgate, London, 37-55.

MommaAs H., 2002. City branding: The necessity of sociocultural goals. In: Florian B., Mommaas H., Speaks M., Synghel Van K. \& Vermeulen M. (eds), City branding, image building and building images. NAI Publishers, Rotterdam, 32-47.

MommaAs H., 2004. Cultural clusters and the post-industrial city: Towards the remapping of urban cultural policy. Urban Studies, 41 (3): 507-532.

Montgomery J., 2004. Cultural quarters as mechanisms for urban regeneration. Part 2: A review of four cultural quarters in the UK, Ireland and Australia. Planning, Practice \& Research, 19 (1): 3-31.

O'ConNor J., 2009. Creative industries: A new direction? International Journal of Cultural Policy, 15 (4): 387-402.

PORTER M.E., 1998. Clusters and the new economics of competition. Harvard Business Review, 76: 77-91. 
PRATT A.C., 2004. Creative clusters: Towards the governance of the creative industries production system? Media International Australia, 112: 50-66.

RAINS S., 1999. Touring Temple Bar: Cultural tourism in Dublin's cultural quarter. International Journal of Cultural Policy, 6 (1): 1-16.

Rigopoulos D., 2012. The crisis kills the historic meeting points of Athens. Kathimerini, 9 March 2012 (in Greek).

RoODHOUsE S., 2006. Cultural quarters, principles and practices. Intellect, London.

Santagata W., 2002. Cultural districts, property rights and sustainable economic growth. International Journal of $U r$ ban and Regional Research, 26 (1): 9-23.

Scotт A.J., 2000. The cultural economy of cities: Essays on the geography of image-producing industries. Sage, London.

SHAW K., 2005. The place of alternative culture and the politics of its protection in Berlin, Amsterdam and Melbourne. Planning, Theory and Practice, 6 (2): 149-169.
Smit A., 2011. The influence of district visual quality on decisions of creative entrepreneurs. Journal of American Planning Association, 77 (2): 164-184.

Sneed S., Runyan R., Swinney J. \& Lim H.J., 2011. Brand, business mix, sense-of-place: Do they matter downtown? Journal of Place Management and Development, 4 (2): 121134.

Souliotis N., 2012. Cultural economy, sovereign debt crisis and the importance of local contexts: The case of Athens. Cities (in press).

TeEgan N, 2010. Are creative classes designed to work with no fixed abode? Occupy Paper 5: 34-38, downloaded from www.occupyspace.com [accessed 30 June 2012].

URRY J., 1990/2002. The tourist gaze: Leisure and travel in contemporary societies. Sage, London.

ZHENG J., 2011. Creative industry clusters and the 'entrepreneurial city' of Shanghai. Urban Studies, 48 (16): 35613582. 